\title{
A Comparative Study of English and Chinese Proverbs Using Natural Semantic Metalanguage Approach
}

\author{
Qiling Wu \\ Correspondence: Qiling Wu, Department of Foreign Languages and Literatures, Beijing Normal University, Beijing, China.
}

Received: January 9, 2019 Accepted: February 11, 2019 Online Published: February 20, 2019

doi:10.11114/ijecs.v2i1.3951

URL: https://doi.org/10.11114/ijecs.v2i1.3951

\begin{abstract}
The current study investigates the similarities and differences between 'equivalent' proverbs in English and Chinese. It integrates natural semantic metalanguage (NSM) into a semantic and pragmatic analysis to explain differences in proverbs as cultural linguistic artifacts. In this study, NSM has enabled the cultural meanings behind the artifacts to be brought into stark contrast for careful qualitative discourse analysis. The findings of the study indicate that it is not only worthwhile but also practical to carefully examine English and Chinese proverb pairs, as their respective meanings may differ, offering unique insight into certain cultural factors. There is much potential for further research on linguistic cultural indicators such as proverbs, song lyrics, and idioms.
\end{abstract}

Keywords: linguistics, proverbs, natural semantic metalanguage

\section{Introduction}

People who share a history, experiences, and geographical background develop a culture. A notably important aspect of culture is that these cultural artifacts are not biologically inherited but rather learned, shared, and passed down as a group. The increasing diversity of the world population has thus been a stimulus to develop a deeper understanding of cross-cultural communication, which includes sensitivity to different values, beliefs, and social patterns. Hall and Hall (1983) divided the world of communication into three parts: words, material things, and behavior. Further, they proposes that the connection between words and behavior is silent language, "a vast unexplored region of human behavior that exists outside the range of people's conscious awareness", which includes a broad range of "evolutionary concepts, practices, and solutions to problems" rooted in the shared experiences of ordinary people (p. 199). However, they also notes that "there is one element lacking in the cross-cultural field, and that is the existence of adequate models to enable us to gain more insight into the processes going on inside people while they are thinking and communicating" (p. 91). Thus, more attention should be paid not only to the study of words, which comprise language, but also to the study of silent language.

There are different forms of words, among which, proverbs, as ubiquitous expressions rooted in culture, are closely associated with silent language. According to Mieder (2004, xi), "Proverbs contain everyday experiences and common observations in succinct and formulaic language, making them easy to remember and ready to be used instantly as effective rhetoric in oral or written communication". Norrick (1985) also notes that a proverb is "a brief, decontextualized, self-contained statement with axed form that conveys a sense of folk wisdom and traditionalism" (p. 78). Proverbs thus deliver cultural knowledge and express the life experiences of human beings. Though numerous scholars have suggested that the role of language in reproducing the shared knowledge of a culture provides insight into the values and beliefs of those who utilize the language (Baetu \& Baker, 2010; Caldwell \& Millen, 2010), proverbs have not attracted the same degree of interest as metaphor and metonymy. Therefore, this paper is focused on investigating eastern and western cultural differences, especially in terms of folk wisdom and traditionalism, by comparing pairs of Chinese and English proverbs.

Although proverbs have not gained wide-spread scholarly attention, several studies about cross-cultural differences with reference to proverbs have been performed. For example, Charteris-Black (1995) studied the social effect of proverbs on figurative language, polite behavior, and topic control among groups of people. Obeng (1996) also compared traditional proverbs from different cultures and discussed the mitigatory role of proverbs in minimizing the offensive intent of an utterance. Briggs (1985) studied the features of performances of proverbs by Mexicanos in northern New Mexico and proposed that proverbs play a role in "connecting basic cultural and linguistic patterns with the minute details of an ongoing social interaction" (p. 793). Joining these noted linguists and anthropologists, psychologists 
Brown and Lenneberg (1954) have also investigated the use of proverbs among Zuni Indians from a cognitive perspective. In the social sciences, Weber and Hsee (1998) also conducted two studies comparing national proverbs related to risk and risk-taking to "gain a better understanding of the sources of observed national differences" (p. 172). These scholars have all examined proverbs in cross-cultural contexts to gain insight into how proverbs reflect cultural thoughts and behaviors.

Based on previous studies, we can say that because of the similarities and differences between eastern and western culture, there must be similarities and differences between Chinese proverbs and English proverbs. Thus, some English proverbs can be directly translated into Chinese, while others may be less compatible. On this premise, a simple matching exercise proposed by Charteris-Black (1995) in which students attempt to find proverbs in one language that are equivalent to a certain proverb in another language needs further consideration. On the one hand, the matching exercise helps learners understand foreign proverbs from the perspective of their first language and thus "recognize the existence of a certain proverb or culture in another language" (Neale, 2015). On the other hand, this simple matching exercise conveys the message that there is no difference between these two proverbs in different languages. This may prevent language learners from understanding cultural differences and the accurate usage of a certain proverb. Thus, we call on a more precise tool to analyze the meaning of proverbs, namely, natural semantic metalanguage (NSM) semantic explications.

NSM, corresponding to the common core of all language, is a mini-language based on a small set of lexical universals or near-universals and a small set of universal or near-universal syntactic patterns. It is the outcome of extensive cross-linguistic empirical studies carried out over two decades by Anna Wierzbicka and her colleagues (Wierzbicka, 1996; Goddard \& Wierzbicka, 2002). Originating with Wierzbicka (1972), the system has been developed and refined over 45 years. The outcome has been a tentatively identified set of lexical universals and the development of a universal metalanguage. The latest version of the lexicon of this metalanguage includes a small subset of word meanings (sixty-three in all), together with a subset of their associated grammatical properties.

Table 1. Universal human concepts-English exponents of language primitives adapted from Levisen and Waters, 2017

\begin{tabular}{ll}
\hline Substantives & I, you, someone, people, something/thing, body \\
\hline Relational substantives & Kind, part \\
\hline Determiners & This, the same, other/else/another \\
\hline Quantifiers & One, two, some, all, much/many, little/few \\
\hline Evaluators & Good, bad \\
\hline Descriptors & Big, small \\
\hline Mental predicates & Think, know, want, feel, see, hear \\
\hline Speech & Say, words, true \\
\hline Actions, events, movement & Do, happen, move \\
\hline Existence, possession & Be (somewhere), there is, be (someone/something), (is) mine \\
\hline Life and death & Live, die \\
\hline Time & When/time, now, before, after, a long time, a short time, for some time, moment \\
\hline Space & Where/place, here, above, below, far, near, side, inside, touch (contact) \\
\hline Logical concepts & Not, maybe, can, because, if \\
\hline Intensifier, augmentor & Very, more \\
\hline Similarity & like/as/way \\
\hline
\end{tabular}

These elements have their own language-independent syntax. For example, nominal personal elements such as "I", "you", and "someone" are combined with verbs such as "think", "know", "say", "feel" and "want"; the combinatorial syntactic properties of language primitives constitute a universal grammar, such as "I think", "someone does not want this", and "you did something bad". As for the essence of NSM, according to Wierzbicka (2010), it rests on the principles that (1) the words used in the process of explication should be very simple and understandable to all speakers of English, and (2) the explication should contain no loss or addition of meaning from a certain language to any other language. 
Wierzbicka (1992) proposes that the function of NSM is to describe the indescribable and offer clues to different cultures. For example, NSM provides a point of access for scholars to explore human emotions from a universal perspective, independent of any particular language or culture. In addition to facilitating analysis of human emotions, this can also facilitate analysis of other cultural artifacts, such as religion, moral concepts, names and titles. NSM is thus argued to be an "invaluable descriptive tool for the analysis and contrastive study of meaning-related phenomena in all languages" (Goddard, 2010). Utilizing such a descriptive tool to compare different ways of thinking reflected in different speech expressions, we can also find the clues to different cultures.

This paper is thus organized as follows. In section 2.0, two pairs of proverbs are analyzed using NSM explication. One pair is 'Birds of a feather flock together' and '物以类聚, 人以群分' (lit., 'objects are united according to their categorization, and people are always divided into factions.'), and the other is 'One can't have one's cake and eat it too' and '鱼与熊掌不可兼得' (You can’t have fish and bear's paw).

\section{Analysis and Discussion}

\subsection{Proverbs 1: 'Birds of A Feather Flock Together' and '物以类聚, 人以群分'}

\subsubsection{English Proverb 1: Birds of a Feather Flock Together}

Though the meaning of these proverbs may seem very close, the proverbs can be employed in different types of everyday discourse, which is influenced most heavily by culture. Thus, the first step in comparing the proverbs is to investigate the corpora containing the proverbs and examine how the proverbs are used in differing everyday contexts. The following three excerpts were retrieved from CNN and FIC and contain the English proverb 'Birds of a feather flock together'.

\section{Text 1.1}

Kuriansky: When you have a trio like Britney and Lindsay and Paris, and - where they're taking and stealing each other`s boyfriends and then get angry, and - it's a love-hate relationship that's not based on what we know as the best kind of relationship.

Hammer: But let's forget them for a minute. SHOWBIZ TONIGHT can tell you the newest friendship all Hollywood is talking about: Katie Holmes and Posh Spice. Katie showing Posh around Hollywood, where Posh and husband David Beckham will soon call home.

Unidentified Female: I was glad to see Katie get out the house. I'm going to be honest.

Unidentified Female: Yes. Really? OK. You right. You right.

Unidentified Female: Even if it is with Posh Spice.

(Crosstalk)

Unidentified Female: Maybe she can get Posh Spice to eat.

Unidentified Female: I mean, what do they talk?

Unidentified Female: You're thin. So are you.

Hammer: So why do celebrities find best friends in other celebrities?

Kuriansky: Birds of a feather flock together, and a best friend basically shows either you who are now, or who you really want to be. [CNN]

\section{Text 1.2}

"If I'm Paul Revere, you are John Hancock," she said, throwing a wad of napkins my way. "The observer, the secretary of us four girls of Massachusetts. We, the girly girls of Massachusetts, whose current goal is to pick a surfer boy, one for each."

\section{Dear Caroline,}

We, the girly girls of Massachusetts, we lead lives we cannot forget. We lead lives and endure the consequences. We lead them and look back at them, knowing friends in need are friends indeed, sorrow falls on the heels of mirth, birds of a feather flock together, and in the end, silence gives consent.

Bonner then joined Lydia, who was still squealing, wiping tears of laughter from her eyes, trying to recover from the sight of Margs sitting in her underwear. [FIC] 


\section{Text 1.3}

If you find it necessary to be your friends' shadow in order to protect them from themselves for your own protection it might be time to consider finding a new set of friends. Remember, as easy as it is to say "It can't happen to me," it's just as easy for friends to influence you to do something you wouldn't ordinarily consider. There's a reason they say "Birds of a feather flock together." With knowledge comes responsibility. It's everyone's responsibility to remind others that alcohol is a drug that can have immediate, deadly effects if abused. [FIC]

The Cambridge Dictionary explains the meaning of 'Birds of a feather flock together', stating it is "said about people who have similar characters or interests, especially ones of which you disapprove, and who often spend time with each other" (2013). The Merriam-Webster Dictionary presents its meaning as "people who are alike tend to do things together". Similarly, these three texts about relationships utilize 'Birds of a feather flock together' as an explanation for certain parties being united. With the metaphor 'birds of a feather' comes the implication that the actresses referred to by the proverb had similar characteristics and then got together. In this instance, having the same character or interests is the primary reason for a group of people to get together. This causal relationship is clearly indicated in Text 1.1, in which the proverb is used to explain the reason why "celebrities find best friends in other celebrities". This line is also representative of the NSM explanation of the proverb, that is, it paraphrases the proverb's explanation of people becoming united. However, from another perspective, Text 1.3 stresses 'flock together,' indicating that people sharing similar interests or characteristics tend to do things together. This recurrence implied in 'Birds of a feather flock together' can be rendered in NSM as follows:

NSM explanation

something like this often happens:

Someone likes something, this someone wants something,

this someone wants to be somewhere,

some people like the same thing, these people want the same thing,

because of this, when this someone is to be somewhere,

this someone wants to be with these people

The main metaphors within this proverb, 'birds of a feather' and 'flock together', can also be defined using image schemas. Image schematic structures refer to those relatively simple structures and spatial orientations that we frequently encounter in our daily experience and are related to our bodies. The image of a concept may result from diverse selective angles, thinking modes,and emphases in individuals' cognition. Furthermore, a schema is an abstractexpression drawn from the subjective experience of individuals. In this sense, 'Birds of a feather', a metaphor that represents people with the same characters and interests, and 'flock together', which represents people united in action or location, aligns with the physical perception and visual perception schemas.

2.1.2 Chinese Proverb 2: 物以类聚, 人以群分 (Lit., 'Objects are United According to Their Categorization, and People are Always Divided Into Factions.')

Having investigated the basic meaning of 'Birds of a feather flock together' and its schematic image structures, we will now examine the Chinese proverb ‘物以类聚, 人以群分', listed as an equivalent proverb to 'Birds of a feather flock together'.

\section{Text 2.1}

俗话说: 物以类聚, 人以群分。这两个贼自从相识到互相知根知底后, 就 好得可以穿一条裤子了, 不但口头上称兄道弟, 还时不时串门做客, 交流 偷鸡心得。

(As the saying goes '物以类聚，人以群分'. The two thieves got along well and could even wear a pair of trousers since they met each other and knew each other. Not only did they verbally say that they were brothers, but they also visited each other and exchanged stealing experiences.)

Text 2.2

汲黯最敬佩的就是袁盎的为人, 我们知道物以类聚, 人以群分, 如果汲黯这样的人最敬佩袁盎, 袁盎会是 小人吗？所以袁盎不是小人。 
(What Ji An admired most is the humanity of Yuan Ang. We know that '物以类聚, 人以群分'. If Ji admired Yuan most, how could Yuan be a villain? Thus, Yuan is not a villain.)

Text 2.3

特别是在用人方面, 作为一名“总统”, 在任命内阁最高首长的时候, 最忌讳的是“物以类聚、人以群分”, 要敢于任用那些与自己可以“取长补短”的人，也就是从性格和作风上和自己都有些“格格不入”的人。

(A president should avoid ‘物以类聚, 人以群分” when he nominates his cabinet. He should be bold

enough to employ those who are different from himself either in characteristics or working styles and

complement one another.)

Text 2 (2.1-2.3) share similarities with Text 1 (1.1-1.3) containing 'Birds of a feather flock together'. Texts in both sets appear to use the proverbs to describe relationships among people, especially a group of people sharing something in common. However, subtle differences still exist between these two proverbs, and NSM is the proper tool for examining these differences in detail. The NSM explication analysis of '物以类聚，人以群分” is as follows.

Text 1.1 perhaps best represents this proverb's NSM explanation. This text uses the proverb to show the addressee's negative qualities, which make him or her the same as other people who engage in bad behaviors. While this meaning agrees partially with "Birds of a feather flock together", as they both emphasize the similarity between an individual and others, as indicated by 'of a feather', '类' and '群', the function of the Chinese proverb in the texts is different from that of the English proverb. In the Chinese texts, ‘物以类聚, 人以群分' functions as a reason for the previous or following statements. To take Text 2.1 as an example, ‘物以类聚, 人以群分’ explains why the two thieves are attracted to each other. Similarly, in Text 2.2, that Yuan is not a villain is deduced from the fact that (1) what Ji An admired most is the humanity of Yuan Ang and (2) ‘物以类聚, 人以群分'. Though the proverb has the same function in Text 2.3, this passage stresses its application in politics. Compared with the Chinese texts, the English ones, however, focus closely on the causal relationship between similar characteristics or interests and people getting together. The following NSM explication thus takes this aspect into consideration to explain the recurrent situation '物以类聚，人以群分”.

$$
\begin{aligned}
& \text { NSM explication } \\
& \text { something like this often happens: } \\
& \text { Something is of a kind, } \\
& \text { other things are of the same kind, } \\
& \text { because of this, when this something is somewhere, } \\
& \text { the other things are there. } \\
& \text { Someone is of a kind, } \\
& \text { other people are of the same kind, } \\
& \text { because of this, when this someone is somewhere, } \\
& \text { the other people are there. }
\end{aligned}
$$

The following table, Table 2, which aligns and compares the NSM explications of the English proverb and its corresponding Chinese proverb, graphically enables a better understanding of the similarities and differences between the English and Chinese proverbs.

Table 2. NSM explications of 'Birds of a feather flock together' and '物以类聚，人以群分”

\begin{tabular}{cl}
\hline Birds of feather flock together & 物以类聚, 人以群分 \\
\hline $\begin{array}{l}\text { something like this often happens: } \\
\text { Someone likes something, this someone wants something, } \\
\text { this someone wants to be somewhere, }\end{array}$ & $\begin{array}{l}\text { something like this often happens: } \\
\text { Something is of a kind, } \\
\text { other things are of the same kind, } \\
\text { some people like the same thing, these people want the same } \\
\text { because of this, when this something is somewhere, } \\
\text { thing, }\end{array}$ \\
$\begin{array}{l}\text { the other things are there. } \\
\text { because of this, when this someone is to be }\end{array}$ & $\begin{array}{l}\text { Someone is of a kind, } \\
\text { other people are of the same kind, } \\
\text { somewhere, }\end{array}$ \\
$\begin{array}{l}\text { because of this, when this someone is somewhere, } \\
\text { this someone wants to be with these people }\end{array}$ & \begin{tabular}{l} 
theople are there. \\
\hline
\end{tabular}
\end{tabular}

Examining the two explications in this manner, it is clear that though they share similarities, there are also subtle differences between them. 'Birds of a feather flock together' describes the causal relationship between people having similar characters or interests and people getting together. The hypothetical actors are people who share some common characteristics. Further, this group of people also performs the action of getting together. The Chinese proverb “物以类 
聚, 人以群分', on the other hand, is used as part of the texts' reasoning, making it an integrated and logical statement. Thus, the subtle differences, instead of being completely ignored, should have attention called to them in linguistics through NSM explication, which can offer not only a way to better understand the proverbs but also a window into different thinking models or perspectives in different cultures. From this point of view, it is worthwhile to further examine the substitution of a proverb for another proverb in another language.

Do similar differences exist between other English-Chinese proverb pairs? Can NSM explication be further employed to closely examine the similarities and differences? This study now presents an examination of the proverbs, 'One can't have one's cake and eat it too' and the Chinese counterpart, '鱼与熊掌不可兼得'.

\subsection{Proverbs 2: 'One can't Have One's Cake and Eat it too' and '鱼与熊掌不可兼得'}

\subsubsection{English Proverb 3: One can't Have One's Cake and Eat it too}

The Cambridge Dictionary defines this English proverb as "to have or do two good things at the same time that are impossible to have or do at the same time" (2013). The following texts were randomly selected from the Corpus of Contemporary American English (COCA) and contain 'One can't have one's cake and eat it too'.

Text 3.1

We sit side by side on the bed, and I start to spill my guts.

"I'm going to tell her. I'm going to tell Galina about what's been going on. And

then you have to choose. Her or me. You don't get to have your cake and eat it too."

"Wait, wait, wait, slow down. Where's this coming from? You're making me feel a little ambushed right now, okay? Look, I really care about you, but I thought you understood that I'm not in a place right now where I can just...”[FIC]

\section{Text 3.2}

The editors of the journal deemed it "of no obvious relevance to physics." But Higgs persevered (and his revised paper appeared later that year in another journal), and physicists who took the time to study the proposal, gradually realized that his idea was a stroke of genius, one that allowed them to have their cake and eat it too. [MAG]

\section{Text 3.3}

Kate Snow: We're taking a look at the age-old debate for new parents. Do you stay home with the kids or do you go back to work? But these days, you might not have to choose. ABC's Juju Chang joins us. This is so interesting.

Juju-Chang: Exactly. Why not have your cake and eat it too, right? Because a growing number of companies are now allowing new parents to take their babies to work. It's a huge benefit for new parents who don't want to put their babies in daycare right away. And it helps smaller businesses that don't want to lose strong employees. But not everyone around the break room thinks it's such a great idea. [ABC]

The use of the phrase was recorded as early as 1538 by Thomas, Duke of Norfolk, as meaning that "a man cannot have his cake and eat his cake." The proverb literally means "you cannot simultaneously retain your cake and eat it". Once the cake is eaten, it is gone. The three sample texts demonstrate how 'One can't have one's cake and eat it too' is used to express the impossibility of having something both ways if those two ways conflict. However, Texts 3.2 and 3.3 apply the adapted version "Have your cake and eat it too", which means to have or do two good things at the same time that seem to be impossible. This adaption is always used as a metaphorical utterance in advertisements. In Text 3.1, because choosing "her" contradicts choosing "me", "you" can choose only one, and you cannot choose both at the same time. In text 3.2, "his idea was a stroke of genius" because it allowed physicists to do two incompatible things, and Text 3.3 implies that the "growing number of companies...now allowing new parents to take their babies to work" helps new parents to have two valuable things at the same time - a job and the opportunity to care for their children. We can thus deduce the NSM explication of 'One can't have one's cake and eat it too' from these three sample texts:

NSM explication

something like this often happens:

Someone wants something in one way, this something in one way is very good.

This someone wants the same thing in different ways, this same thing in different ways is very good. 
This someone can have this something but cannot have the other thing or this someone can have the other thing but cannot have this something

\subsubsection{Chinese Proverb 4: 鱼与熊掌不可兼得 (Lit., 'You can’t Have Both Fish and Bear’s Paw')}

This section examines three randomly selected texts from the COCA containing ‘鱼与熊掌不可兼得'.

Text 4.1

不巧的是, 刚好我的同事们又要去新疆喀纳斯了, 我的时间表冲突了。有时候, 人生的确是鱼与熊掌不能 兼得的。

(Unfortunately, my colleagues are going to Kanas, Xinjiang, again, which conflicts with my schedule. Our life is indeed 鱼与熊掌不能兼得.)

\section{Text 4.2}

为了当初的选择已经失去了很多幸福, 我不想重走爸爸的老路。可是现实只能让你选熊掌或鱼的时候, 你 就必须有壮士断腕的勇气了。

(I have lost much happiness because of the choice. Now I don't want to follow dad's way again. However, when reality just allows you to choose 熊掌或鱼, you must have the courage to make a quick fatal decision.)

Text 4.3

高额的保障, 合理的费用, 鱼与熊掌如何兼得? 生命人寿为您提供完美的解决方案。

(High security and reasonable cost, 鱼与熊掌如何兼得? Sino-Life gives you a

perfect solution.)

It is clear that these three Chinese sample texts convey the meaning of '鱼与熊掌不可兼得' as making a choice between two valuable things. However, one of the two things possesses a higher value than the other. In Text 4.1, the speaker wishes to go to Xinjiang, but it does not fit his/her schedule. However, before the speaker makes the utterances, he/she has already made the decision to follow his/her schedule. The same meaning is seen within Text 4.2: faced with two choices, the speaker has to choose to give up his own belief. Text 4.3 adopts an adapted version, “鱼与熊掌如何兼 得”, because of its function - advertising. We thus obtain the following NSM explication of “鱼与熊掌不可兼得' from these three sample texts:

NSM explication

something like this often happens:

Someone wants something, this something is very good.

This someone wants the other thing, this thing is very good.

This something is better than the other thing or the other thing is better

than this something.

This someone can have this something but cannot have the other thing

or this someone can have the other thing but cannot have this

something.

Because of this, this someone wants the better of the two things.

For a concise, simultaneous, and graphic examination of these English and Chinese proverbs, we present Table 3, which aligns and compares the complete NSM explications for the English proverb 'One can't have one's cake and eat it too' and the corresponding Chinese proverb ‘鱼与熊掌不可兼得'.

Table 3 demonstrates that while ‘鱼与熊掌不可兼得' and 'One can't have one's cake and eat it too' have very similar meanings and contain similar components, they differ in notable ways. ‘鱼与熊掌不可兼得' literally means that you cannot have both fish and bear's paw. This proverb originates from Mencius's statement, "Fish, I want; bear's paw, I want. I cannot have both of them, thus, I abandon fish and get bear's paw". There is a value difference between fish and bear's paw. Therefore, this proverb indicates that before speakers have made the utterance, they have already settled on their decision, and the decision is to abandon fish and choose bear's paw. However, 'One can't have one's cake and eat it too' is used to emphasize the impossibility of having something both ways. This is another example of a Chinese proverb with a similar but subtly different meaning from that of its counterpart English proverb. 
Table 3. NSM explications of 'One can’t have one's cake and eat it too' and '鱼与熊掌不可兼得'

\begin{tabular}{|c|c|}
\hline One can't have one's cake and eat it too & 鱼与熊掌不可兼得 \\
\hline something like this often happens: & something like this often happens: \\
\hline $\begin{array}{l}\text { Someone wants something in one way, this } \\
\text { something in this way is very good. }\end{array}$ & $\begin{array}{l}\text { Someone wants something, this something is } \\
\text { very good. }\end{array}$ \\
\hline \multirow{5}{*}{$\begin{array}{l}\text { This someone wants the same thing in different } \\
\text { ways, this same thing in different ways is very } \\
\text { good. } \\
\text { This someone can have this something but } \\
\text { cannot have the other thing } \\
\text { or this someone can have the other thing but } \\
\text { cannot have this something }\end{array}$} & $\begin{array}{l}\text { This someone wants the other thing, this thing } \\
\text { is very good. }\end{array}$ \\
\hline & $\begin{array}{l}\text { This something is better than the other thing or } \\
\text { the other thing is better than this something. }\end{array}$ \\
\hline & $\begin{array}{l}\text { This someone can have this something but } \\
\text { cannot have the other thing }\end{array}$ \\
\hline & $\begin{array}{l}\text { or this someone can have the other thing but } \\
\text { cannot have this something. }\end{array}$ \\
\hline & $\begin{array}{l}\text { Because of this, this someone wants the better } \\
\text { one of the two things. }\end{array}$ \\
\hline
\end{tabular}

\section{Conclusion}

This study has shown that two equivalent, according to a dictionary, English and Chinese proverbs actually have a number of subtle differences easily examined by NSM explication. 'Birds of a feather flock together' describes the causal relationship between people having similar characters or interests and people getting together. The hypothetical actors are people who share some common characteristics. Further, these people also perform the action of getting together. The Chinese proverb '物以类聚, 人以群分', on the other hand, is used as an element of reasoning, making it an integrated and logical statement. Thus, the NSM explication offers not only a way to better understand these proverbs but also a window into different thinking models or perspectives in different cultures. With respect to 'One can't have one's cake and eat it too' and '鱼与熊掌不可兼得', the latter indicates that even prior to the speakers using the proverb, they have already made their decision, that is, to 'abandon fish and choose bear's paw', while the former does not convey the same thing. This is another example of a Chinese proverb with a similar but subtly different meaning from that of its counterpart English proverb. Because of these differences, the proverbs were used differently in the sample texts. Comparison between cultural linguistic artifacts such as proverbs is no longer restricted to semantic and pragmatic analysis; NSM explication can also be successfully integrated into comparative studies. These results indicate that it would be not only worthwhile but also extremely practical to examine other English and Chinese proverb pairs, as their meanings may also differ due to certain cultural factors worthy of note and the effort made to achieve deeper understanding.

\section{Acknowledgements}

I am very grateful to Miles Neale from the University of Queensland for his "A Comparison of English and Japanese Proverbs Using Natural Semantic Metalanguage". I get inspiration from his paper and conduct this replication.

\section{References}

Baetu, I., \& Baker, A. G. (2010). Extinction and blocking of conditioned inhibition in human causal learning. Learning \& Behavior, 38(4), 394-407. https://doi.org/10.3758/LB.38.4.394

Briggs, A. (1985). The BBC: The first fifty years. Oxford University Press, USA.

Brown, R. W., \& Lenneberg, E. H. (1954). A study in language and cognition. Journal of Abnormal and Social Psychology, 49(3), 454-462. https://doi.org/10.1037/h0057814

Caldwell, C. A., \& Millen, A. E. (2010). Human cumulative culture in the laboratory: Effects of (micro) population size. Learning \& Behavior, 38(3), 310-318. https://doi.org/10.3758/LB.38.3.310

Charteris-Black, J. (1995). Proverbs in communication. Journal of Multilingual \& Multicultural Development, 16(4), 259-268. https://doi.org/10.1080/01434632.1995.9994606

Charteris-Black, J. (1999). The survival of English proverbs: A corpus-based account. An Electronic Journal of International Proverb Studies, 5(2).

Goddard, H. C. (2009). The meaning of Shakespeare , 1. University of Chicago Press. 
Goddard, C. (2010). The natural semantic metalanguage approach. The Oxford Handbook of Linguistic Analysis, 459-484

Goddard, C., \& Wierzbicka, A. (Eds.). (2002). Meaning and universal grammar: Theory and empirical findings (Vol. 1). John Benjamins Publishing.

Hall, E. T., \& Hall, M. R. (1983). Hidden differences: studies in international communication; how to communicate with the Germans. Stern.

Levisen, C., \& Waters, S. (Eds.). (2017). Cultural keywords in discourse (Vol. 277). John Benjamins Publishing Company. https://doi.org/10.1075/pbns.277

Mieder, W. (2004). Proverbs: A handbook. Greenwood Publishing Group.

Neale, M. (2015). A Comparison of English and Japanese Proverbs Using Natural Semantic Metalanguage. New Voices in Japanese Studies Volume 7.

Norrick, N. R. (1985). How proverbs mean: Semantic studies in English proverbs (Vol. 27). Walter de Gruyter. https://doi.org/10.1515/9783110881974

Obeng, S. G. (1996). The proverb as a mitigating and politeness strategy in Akan discourse. Anthropological linguistics, 38 (3), 521-549.

Weber, E., \& Hsee, C. (1998). What folklore tells us about risk and risk taking: Cross-cultural comparisons of American, German, and Chinese proverbs. Organizational Behavior and Human Decision Processes, 75(2). https://doi.org/10.1006/obhd.1998.2788

Wierzbicka, A. (1972). Semantic primitives. (Frankfurt/M.) Athenäum-Verl.

Wierzbicka, A. (1992). Semantics, culture, and cognition: Universal human concepts in culture-specific configurations. Oxford University Press on Demand.

Wierzbicka, A. (1996). Semantics: Primes and universals: Primes and universals. Oxford University Press, UK.

Wierzbicka, A. (2010). Experience, evidence, and sense: The hidden cultural legacy of English. Oxford University Press on Demand.

\section{Copyrights}

Copyright for this article is retained by the author(s), with first publication rights granted to the journal.

This is an open-access article distributed under the terms and conditions of the Creative Commons Attribution license (http://creativecommons.org/licenses/by/4.0/). 